\title{
Enacting Freedom of Information Act in Malaysia: A Cost-Benefit Analysis
}

\author{
Muhammad Izwan Ikhsan ${ }^{*}$ (iD, Lenny James Matah² \\ 1Universiti Teknologi MARA, Sabah Branch, Malaysia. \\ Email: izwanikhsan@uitm.edu.my \\ 2Universiti Teknologi MARA, Sabah Branch, Malaysia. \\ Email: lenny442@uitm.edu.my
}

\section{CORRESPONDING \\ AUTHOR (*): \\ Muhammad Izwan Ikhsan \\ (izwanikhsan@uitm.edu.my) \\ KEYWORDS: \\ Freedom of information \\ Cost-benefit analysis \\ Prismatic interpretation \\ Official secrecy \\ Transparency \\ CITATION: \\ Muhammad Izwan Ikhsan \& Lenny James Matah. (2022). Enacting Freedom of Information Act in Malaysia: A Cost-Benefit \\ Analysis. Malaysian Journal of Social \\ Sciences and Humanities (MJSSH), 7(2), \\ e001297. \\ https://doi.org/10.47405/mjssh.v7i2.1297}

\begin{abstract}
Freedom of information (FOI) refers to the right given to the public to seek information from government bodies. In Malaysia, to date, there is no federal legislation on the right to information. The system of official secrecy under the Official Secrets Act 1972 is the default system of information access. This paper aims to discuss the current constitutional setup, information disclosure system in Malaysia and the cost-benefit analysis of enacting the Freedom of Information Act at the Federal level. This article uses content analysis methods of previous literature, courts' judgements, and statutory interpretation. This article also studies the international paradigm of FOI in various human rights instruments. This article concludes that the arguments favouring enacting the FOI law outweigh the contentions against such regulation.
\end{abstract}

Contribution/Originality: This study contributes to the existing literature on the right to freedom of information in Malaysia because to date, Parliament has not enacted relevant laws. This study proposes the application of a prismatic interpretation of the Constitution to expand the scope of freedom of speech to the right of information. This involves an analysis of the costs and benefits that the legislature may consider.

\section{Introduction}

Freedom of information (FOI) is fundamentally a right given to the people to request information from the government (Mitee, 2017). It also encompasses the obligation of government agencies to publish information on a routine basis (Paterson, 2004). Numerous international and regional legal instruments such as the Universal Declaration of Human Rights (Article 19), International Covenant on Civil and Political Rights (Article 19(2)), European Convention on Human Rights (Article 10(1)), ASEAN Human Rights Declaration (Article 23), and Cairo Declaration on Human Rights in Islam (Article 22(c)) recognise FOI as a fundamental right in a democratic society. The 
universal appeal of FOI has led countries of diverse political, legal and social backgrounds to pass laws providing the right to access information held by the government.

In Malaysia, according to M. Daud and S. Zulhuda (2018), despite having FOI enactments in Selangor and Penang, the federal legislature has yet to attempt bringing FOI motion to be tabled before the Parliament. The absence of a specific national law on FOI inspires the writing of this article which aims to study the prospect and hurdles in enacting FOI law in Malaysia. Essentially, this article seeks to generate a cost-benefit analysis of conflicting opinions regarding the advantages and the problems of such a law. Besides, this article also explores the position of FOI under the Federal Constitution, the framework of official secrecy under the Official Secrets Act 1972 (OSA), and the implementation of FOI Enactments in Penang and Selangor.

\section{Federal Constitution and Prismatic Interpretation}

Strict interpretation: Part II of the Federal Constitution provides fundamental liberties that range from right to life, free speech, expression, assembly, and association, freedom of religion, equality, and property rights. A literal reading of the Constitution does not contain a provision concerning FOI. Article 10(1)(a) provides that every citizen has the right to freedom of speech and expression subject to limitations. Therefore, this raises a question about whether the right to information a species of free speech and expression. Article 159(2) declares that "subject to the following provisions of this Article and Article 161E, the provisions of this Constitution may be amended by federal law". On numerous occasions, the Courts have shown an unwillingness to "rewrite" the Constitution.

For example, in Loh Kooi Choon v The Government of Malaysia [1977] 2 MLJ 187, the Federal Court observed that the judiciary should not enter a political thicket. A policy question should be debated and determined by the Parliament, including those affecting human rights. Similarly, in Datuk Harun v PP [1976] 2 MLJ 116, the Court declared that it has no liberty to stretch or pervert the language of the Constitution in the interests of any legal or constitutional theory or even to supply omissions or of correcting supposed errors. Further, in Phang Chin Hock v Public Prosecutor [1980] 1 MLJ 70, the Federal Court emphasised that the Parliament may amend the Constitution in any way they think fit, provided that they comply with all the conditions precedent and subsequent regarding manner and form prescribed by the Constitution.

In Jabar v PP [1995] 1 SLR 617, the Court underscored that any law is valid and legally binding so long as it is validly passed. It should not be concerned with whether the law is fair, just and reasonable. In Anwar Ibrahim v PP [2011] 1 MLJ 158, the Federal Court followed the judgment in the Indian case of Adananda Pyne v. Harinam Sha AIR [1950] Cal 179, where it was held that:

"Courts must resist the temptation to change the law under cover of interpretation of the law. If they use their power to interpret the law, to alter laws which they may not like, and to make new laws which they think should be made, that would be a corrupt use of their power."

The positivist approach in constitutional interpretation found its footing from the doctrine of parliamentary supremacy as applied in the United Kingdom. In British 
Railway Board v Pickin [1974] AC 765, Lord Reid declared that the function of the Court is to construe and apply the statutes of the Parliament. It has no concern with how the Parliament or officers are performing their operations. In Ghaidan v Mendoza [2004] 3 All ER 411, Lord Millet observed that any change in a fundamental constitutional principle should be the consequence of deliberate legislative action and not judicial activism, however well-meaning. In $R$ (on the application of the Public Law Project) $v$ Lord Chancellor and Secretary of State for Justice [2017] 2 All ER 423, the Court held that in the system of parliamentary supremacy, it is not open to a court to challenge or refuse to apply a statute, save to the extent that Parliament authorises or requires a court to do so.

The attempt to bring in UDHR in interpreting the constitutional provision has been rejected in Merdeka University v Government of Malaysia [1981] 2 MLJ 356, where it was held that the UDHR is not a legally binding instrument and does not form part of the municipal law. Similarly, in Mohamad Ezam bin Mohd Noor v Ketua Polis Negara \& Other Appeal [2002] 4 MLJ 449, the Court held that the UDHR does not bind the Malaysian Courts. Therefore, it is difficult to argue that FOI forms part of free speech due to the absence of express stipulation on FOI in the Malaysian Constitution and the reluctance to interpret constitutional provisions in the light of international instruments.

Distinguishing parliamentary and constitutional supremacy: In Malaysia, judicial activism can be seen in several cases where the Courts aptly rejected the notion of parliamentary sovereignty. For instance, the former Lord President in Ah Thian $v$ Government of Malaysia [1976] 2 MLJ 112 declares that:

"The doctrine of the supremacy of Parliament does not apply in Malaysia. Here we have a written constitution. The Constitution limits the power of Parliament and of State Legislatures in Malaysia, and they cannot make any law they please. Under our Constitution written law may be invalid on one of these grounds:

i. in the case of federal written law, because it relates to a matter to which Parliament has no power to make law, and in the case of state written law, because it relates to a matter which respect to which the State Legislature has no power to make law;

ii. in the case of both federal and State written law, because it is inconsistent with the Constitution or;

iii. in the case of State written law, because it is inconsistent with Federal law.

The Court has the power to declare any Federal or State law invalid on any of the above three grounds. Similarly, in the recent case of Indira Gandhi a/p Mutho $v$ Pengarah Jabatan Agama Islam Perak \& Ors and other appeals [2018] 1 MLJ 545, the Federal Court through Zainun FCJ explained the distinction between the UK's Westminster model and the Malaysian framework, which is premiered on a supreme written Constitution. The Parliament may not make a law that is inconsistent with the Constitution.

It may be argued that the Federal Constitution as a living document should include FOI in the interpretation of Article 10(1)(a). FOI should be regarded as an extension of free speech and expression. It is evident from the Indian Supreme Court's decision in Union of India v Association for Democratic Reforms [2005] SCC 294 where it was held that "onesided information, disinformation, misinformation and non-information, all equally will create an uninformed citizenry which makes democracy a farce. Freedom of speech and 
expression includes the right to impart and receive information which includes freedom to hold opinions."

Prismatic approach: It is suggested that liberal interpretation towards the supreme law must be adopted in this regard. First of all, it is argued that free speech, expression, and information have the combined effect of creating a healthy and meaningful democracy. In Malaysia, Gopal Sri Ram J, in the case of Lee Kwan Woh v PP [2009] 5 CLJ 631 celebrates the liberal interpretation of constitutional provisions. His Lordship declared that the Court has to adopt a 'prismatic approach' when interpreting the fundamental rights guaranteed under the Constitution. Hence, by applying the prismatic approach, it is argued that freedom of speech and expression should not remain stagnant. FOI, which facilitates the enjoyment of freedom of speech and expression, should be regarded as an extension of the constitutionally guaranteed liberties. Contemporary social acceleration of time must be given its due in interpreting laws, especially those affecting the rights of the citizens (Corcoran, 2005). Statutory provisions must be harmonised with the principles of common law, international norms, and obligations.

This approach is consistent with the judgement of the Late Lord President Raja Azlan Shah in Dato Menteri Othman bin Baginda \& Another v Dato Ombi Syed Alwi bin Syed Idrus [1981] 1 MLJ 29 who declared that “... a Constitution, being a living piece of legislation, its provisions must be construed broadly and not in a pedantic way - with less rigidity and more generosity than other Acts." In the context of FOI, it is submitted that we live in an era where people are "hungry for information. Information (regardless of their credibility) are readily available within one click or touch away. Freedom of speech and expression without proper access to information is no more than a legal myth. Using secrecy law to deflect any questioning over the government's inner working is inharmonious with the call for a more transparent and responsive government. Ultimately, to give life to the pledge of openness, it is necessary to extend the breadth of free speech and expression to include freedom to seek, receive and impart information.

\section{The system of official secrecy}

OSA as a British Legacy: As mentioned above, only Selangor and Penang have a specific statutory arrangement on FOI. At the Federal level, no specific statute on FOI has been passed so far. The current framework of the information system is tightly regulated by the Official Secrets Act 1972 (OSA). This statute generally exempts all classified information from disclosure for any purpose (however noble the intention is) unless the proper authority declassifies the said information. The OSA was modelled after the English legislation was first introduced to combat any attempt by civil servants to indulge in spying and espionage. However, the amendment to the OSA in 1986 widens the statute's scope in criminalising all types of communication of official secrets.

Departure from English OSA: The departure of the Malaysian OSA from the original spirit of the English legislation is glaring. In the UK, the offence of unauthorised disclosure under Section 2 requires the prosecution to prove the following ingredients:

- The accused person is or has been a government servant or a government contractor. The provision does not apply to the third party who receives the information. In contrast, the Malaysian OSA applies indiscriminately to anyone who is involved along the chain of communication of classified information;

- The disclosure of the information is done without lawful authority; and 
- The disclosure must be damaging. Communication is detrimental if it damages the intelligence and security services, the capability of the armed forces, international relations, or crime and investigation powers.

The Malaysian OSA does not consider the damaging implication of the disclosure to attract criminal liability under the Act. The Act covers all types of disclosure of any classified document, no matter how trivial or unrelated it is with national security, defence or crime prevention.

Evil intention: Furthermore, it is submitted that Section 8 of the Malaysian OSA creates a strict liability offence; hence the malicious intent of the accused is immaterial. The Court in PP $v$ Lim Kit Siang [1979] 2 MLJ 37 held that the gist of the crime is wrongful communication of information that belongs to the government. In Minister of Energy $v$ MTUC [2013] 1 MLJ 161 the fact that the concession documents were not related to national security is irrelevant in determining whether they are official secrets or not. The contents or nature of the papers are immaterial. These two cases illustrate a contradictory approach practiced in Malaysia compared to the UK's legislative regime. In the UK, the FOI Act 2000 provides that information may only be withheld under the prescribed statutory exemptions, namely:

- Information already accessible;

- Information intended for future publication;

- Bodies dealing with security matters;

- National security;

- Defence;

- International relations;

- Relations within the United Kingdom;

- Economic interests of the United Kingdom;

- Investigations and proceedings conducted by public authorities;

- Law enforcement;

- Court records;

- Audit functions;

- Parliamentary privilege;

- Formulation of government policy;

- Prejudice to the conduct of public affairs;

- Communication with Her Majesty and honours;

- Health and safety;

- Environmental information;

- Personal information;

- Information provided in confidence;

- Legal professional privilege;

- Commercial confidentiality; and

- Prohibition on disclosure.

Statutory presumption: In addition to that, Section 16(3) of the Malaysian OSA makes a statutory presumption that unless otherwise proved, it shall be presumed that unlawful communication of classified information is made for the purpose prejudicial to the national interest. This is not in tandem with the general notion of criminal justice, which imposes the prosecution the burden to prove that the communication is damaging to the national interest. In State v Coetzee [1997] ZACC 2, the Court held that the more serious the crime and the greater the public interest in securing the conviction of the guilty, the 
more constitutional protection should be accorded to the accused. In the context of disclosure of information, it is submitted that proving that the disclosure is damaging does not present any evidential difficulty to the prosecution. For instance, if unauthorised disclosure is made to unearth corruption, the pendulum of justice should favour the expose, even though it was made without lawful authorisation. In contrast, if the disclosure was made about the sensitive security information, the prosecution should bear the burden of so proving.

Ministerial certificate: The Malaysian OSA also contains Executive intervention in the form of a certificate under Section 16A. This section provides that a certification by a Minister or public officer in charge certifying certain information as official secret shall be conclusive evidence of that fact and shall not be questioned in any court. It is submitted that the bar of judicial review by Section 16A may lead to the arbitrary use of the provision hence due to the absence of any check and balance mechanism on the Executive discretion. On the contrary, in the UK, a Ministerial certificate is subject to judicial review. As held by the Information Tribunal in Tony Gosling v Secretary of State for the Home Department (2001) IT, if on an appeal, the Tribunal finds that, applying the principles applied by the Court on an application for judicial review, the Minister did not have reasonable grounds for issuing the certificate; the Tribunal may allow the appeal and quash the certificate. In invoking the certificate, the Minister must also state the reasons for giving such a certificate. In contrast, the Malaysian OSA is silent whether the grounds for certifying information as an official secret must be stated by the Minister.

Judicial courage in Takong Tabari's case: It is argued that the decision of the Court of Appeal in Takong Tabari $v$ Government of Sarawak [1994] MLJU 386 could provide a judicial solution to the unwarranted treatment of official secrets with absolute impunity. It should be the recommended practice in determining the appropriate limits of disclosure and protection of national security interests. In this case, the plaintiff sought the court order for inspection of documents containing reports of an explosion that caused the death of the plaintiff's husband. The document was marked 'SULIT', and it was certified by the Director of Sarawak Public Works Department under the OSA 1972. Richard Malanjum J observed that the primary purpose of the OSA is to deal with the prevention of unauthorised communication of official information whose disclosure would or would likely prejudice public interest or national security. Although the Court was aware that Section 16A of the OSA affirms that a ministerial certificate shall be conclusive evidence of official information, the Court held that it did not prevent the Court from inspecting the document in question under Section 162 of the Evidence Act 1950 (EA).

Essentially, this provision stipulates that a witness summoned to produce a document shall, if it is in his possession or power, bring it to the Court notwithstanding any objection which there may be to its production or its admissibility. The Court shall decide on the validity of any such objection. In addition to that, if it sees fit, the Court may inspect the documents unless it refers to affairs of State or takes other evidence to enable it to determine its admissibility. On Section 16A, his Lordship interpreted that the section does not prohibit the admissibility of information classified as an official secret. Section 16A merely prevents the questioning of the reason for classifying the document as an official secret. Therefore, it is incorrect to invoke that the classification completely excludes it from being disclosed before a court. The Court held that the defendant showed nothing that the document relates to 'the affairs of State' or was it shown of any prejudicial effect on public interest by its disclosure. 


\section{Arguments in support of FOI}

Openness and transparency: First and foremost, FOI fosters openness and transparency in the government. Secrecy in public affairs can only be curtailed by opening the government's windows to the oversight of the people. FOI enables the public to develop a clearer image of what is happening inside the government. Besides, transparency and openness strengthen accountability and enhance the credibility of the political and economic system. If poor performance, inefficacy, dishonesty and duplicity are readily exposed and rooted out by public oversight, this will rekindle the faith in the government. Besides, it also improves the public sector's professionalism and the capacity of the officers to develop, analyse, articulate and implement policies that stand up to public scrutiny. With improved access to government information, it will bring the public closer to the government, hence improving public confidence in the institutions. Transparency and openness will also expose those who might misuse the public office in the darkness of secrecy by allowing the public to pull back the curtain on the operation of the government and see what lies behind the cloth.

Disinfectant of corruption and vices of power: Corrupt behaviour most often occurs behind closed doors. Without public scrutiny on the public institutions, corruption generally lags behind the radar of the anti-corruption enforcement agency and the public alike. Gill highlights that under normal conditions where rules and procedures are honestly complied with, official secrecy will be a minor nuisance to the citizens. However, when the system ceases to follow norms to the extent that every official file is marked as 'confidential' and 'top secret', this secrecy becomes the cloak for irregular, unauthorised or male fide acts of the government (Gill, 1998). In various literature, it was highlighted numerous times that FOI legislation would expose corruption in the government. Making government information and practices open to public inspection should give everyone equal access to government spending, procedures and contracts. As observed by the High Court of Punjab in HPSC, Chandigarh v. State Information Commission \& Anor 2008 (3) SCT 552:

"It is well said sunlight is the best antiseptic and secrecy breeds corruption. If there is openness... it promotes equality, objectivity and impartiality."

The Court further held that:

"...If the information with regard to selection criterion and marks allocated for academic qualification, experience and interview during the selection process is not disclosed to the candidate then their legitimate right to compete in the selection process is likely to be effected adversely. The criterion for selection and marks allocated to various heads are in the public domain and for the benefit of every candidate. The taxpayers who are contributing to the public service are also entitled to know as to how the selection of public servant is being made...."

Control on Executive: FOI can compel public officials to discharge their functions and apply their discretion within the legal limits conferred by the law. In the discharge of general duties, the exercise of discretion is an integral part of the legal system. Nonetheless, when the criterion to apply this discretion is unknown to the public, 
discretionary power is prone to abuse. In Malaysia, the High Court in The Edge's case ruled that the suspension order made by the Home Minister was invalid, irrational and tainted with illegality as it contained "blanket allegation" without specifying the articles that were alleged to be undesirable publications. Besides, the latter had also breached procedural fairness when issuing a show-cause letter (Lim, 2015). The danger of arbitrary discretion was also observed in the Indian case of Women Lawyers Association v State of Tamil Nadu [2009] 7 MLJ 1233 where it was held that "a discretionary power is exercisable by the holder of the authoritative power on the subjective satisfaction of appliance of his intelligent mind on evaluation of facts, prevailing circumstances governing the situation and imminent necessity warranting for operation of his empowerment as well as his answerability and responsibility to the situation." It must not be arbitrary, fanciful and influenced by extraneous considerations. In matters of discretion like this, the choice must have to be dictated by public interest to safeguard law and order.

In the Malaysian case of Sugumaran Balakrishnan v Pengarah Imigresen Negeri Sabah \& Anor [1998] 3 CLJ 85, the High Court observed every organ of the State and every authority under the Constitution in our constitutional scheme derives its power from the Constitution. Therefore, it has to act within the limits of such power. It is a limited government we have under the Constitution. Both the executive and legislature have to act within limits conferred upon them under the Constitution. Hence, the vast discretionary power granted to the public bodies in classifying and declassifying information coupled with the lack of guiding principles in exercising such discretion will ultimately diminish the ability of the citizenry to control and supervise the acts of the public officials. With FOI legislation in place, this will reinforce public control over the conduct of the public officers.

Informed citizenry: The democratic right of a citizen is not merely limited to the right to join a political party and the right to vote during the election. Access to information is a critical aspect of citizenship. In the absence of adequate access to information, the electorates would not make an informed decision based on informed deliberation. Without a system of public access to information, the citizens could not meaningfully participate in the democratic process. Active and direct participation of the citizens in the government's day-to-day affairs and formulation of policies is only possible when the door to the government is unlocked. This will ensure that every decision of the public institution is made to pursue the common good and general interest of the people, not solely to benefit the selected powers. Besides, better and well-informed citizens can more clearly articulate their opinions and concerns on matters of public importance. This will ultimately nurture greater participation in public debate and a reduction of alienation and cynicism.

Theory of representative government: One of the vital cradles of a democratic government is that it is a "government of the people, by the people, for the people", or to put it simply, a representative government. The Constitution establishes a representative democracy not because the majority have the inherent right to rule over the few but because it is the most acceptable way to harmonise and protect equal rights. This majority represents the whole; consequently, it must govern on behalf of all, not to pursue its interests to the detriment of others. In a representative democracy, the role of the electorates should not be limited to "obeying the law and conforming to the choice of leaders whose election gives them the power to enact into law whatever policies they see fit". Cotterrell (1995) stated that citizenship means more than voting once every five 
years and then leaving civic and economic matters for government and the marketplace to sort out. The theory of representative government also upholds that information held by the government belongs to the people. To deny them access to information held on their behalf is a flagrant transgression of the faithful duty of the representatives to act for the best interests of those they represent.

International recognition: International recognition of FOI as a vital human right in numerous human rights conventions affirms the universal value of the freedom to seek and impart information. Article 19 of the Universal Declaration of Human Rights 1948 provides that every person has freedom of opinion and expression. The right includes the freedom to hold opinions without interference and seek, receive, and impart information and ideas through any media regardless of frontiers. The International Covenant on Civil and Political Rights (ICCPR), which came into existence in 1966, is a human rights treaty recognises the freedom to seek, receive and impart information. Still, to date, Malaysia has yet to ratify this Convention. Concerning the acceptance of FOI in regional instruments, Article 10(1) of the European Convention on Human Rights 1950 (ECHR) guarantees the right to information. In contrast, Article 13(1) of the American Convention on Human Rights 1960 (ACHR) also recognises such right. Closer to home, Article 23 of the ASEAN Human Rights Declaration 2012 also recognises FOI in the following words:

"Every person has the right to freedom of opinion and expression, including freedom to hold opinions without interference and to seek, receive and impart information, whether orally, in writing or through any other medium of that person's choice."

History has also shown that countries of diverse political, legal and religious backgrounds have passed laws concerning FOI. The Western World no longer monopolises FOI law. Of course, while Sweden and the US have FOI from decades ago, more countries are joining the list in recent years. Malaysia's close neighbours Thailand, the Philippines, and Indonesia have already passed FOI laws despite being still in the infancy stage. The Islamic Republic of Pakistan legislated the Right to Information Act in 2013, whereas, in April 2007, the State Council of the People's Republic of China promulgated the "Regulations of the People's Republic of China on Open Government Information", which came into effect on 1 May 2008. In addition to that, Commonwealth countries such as India passed its Right to Information Act in 2005. In Australia, there is FOI law at the federal level in the form of the Freedom of Information Act 1982, and at state levels, the respective statutes are as follows:

- Australian Capital Territory, the Freedom of Information Act 1989

- New South Wales, the Government Information (Public Access) Act 2009

- Northern Territory, the Information Act 2003

- Queensland, the Right to Information Act 2009

- South Australia, the Freedom of Information Act 1991

- Tasmania, the Right to Information Act 2009

- Victoria, the Freedom of Information Act 1982

- Western Australia, the Freedom of Information Act 1992.

The African continent is no exception in enacting laws on FOI. For example, Article 32 of the Constitution of South Africa guarantees the right of access to any information held by the State. This right is implemented through the Promotion of Access to Information Act 2000. Additionally, in Zimbabwe, the Access to Information and Privacy Act (AIPPA) was 
signed by President Robert Mugabe in February 2002. It is submitted that the existence of FOI law across geographical borders, beyond religious, social, political and legal dissimilarities, further substantiates the universal value of FOI. Malaysia has the privilege of being appointed as the non-permanent member of the UN Security Council for the fourth time: 1964-1965, 1989-1990, 1999-2000 and recently 2015-2016. As a vocal member at the international front, it is only appropriate if it fulfils its human rights commitment back home, especially in enacting FOI law, which is recognised under numerous international treaties and international customary law.

\section{Arguments against FOI}

Cost: While FOI implementation benefits combating corruption, exposing and preventing abuse of power and fostering informed citizenry, the issue of cost is also cardinal. Data presented to the Justice Select Committee in the UK in 2012 shows that FOI spending of the Ministry of Justice is at $£ 0.93 \mathrm{k}$, followed by the Department of Work and Pensions at $£ 0.92 \mathrm{k}$ and Home Office at $£ 0.9 \mathrm{k}$. Meanwhile, the FOI spending of the Ministry of Defence and Ministry of Transport is at $£ 0.85 \mathrm{k}$ respectively. Prime Minister David Cameron told the committee that FOI was "furring up the arteries" of government. When public sector budgets are being slashed, it can be difficult to defend the costs of freedom of information (Flyn \& Harper, 2012). Critics of FOI often concentrate on the costs of FOI's compliance with the government, both in financial and staff terms. According to Stearman (2012), they argue that while it is easy to talk about the benefits of FOI, in reality, it poses problems for those who need to deliver the service. He further stated that the government needs to draft and adopt a new law, determine how it has to be implemented and establish an organisation to oversee the law. Besides, it also needs to publicise the law in government agencies, train the civil servants, teach them how to deal with the law, and educate the public and create awareness on how to use the access right. A bigger problem, according to the critics, is the operational cost of implementing FOI. They are concerned that hardworking civil servants will be diverted from discharging their essential duties as they are flooded with numerous FOI requests; some of them are repeated, frivolous or vexatious. The engagement of extra staff employed just to reply to FOI requests will likely increase the government's costs (Stearman, 2012). In response to this, it is submitted that the government has to balance the cost of implementing FOI and the revenues it could lose should secrecy is allowed to flourish in the public institutions. The government can generate income by introducing a subscription system to information access. Cost can also be reduced by the implementation of an online system of information requests.

The administrative burden on the government: The Minister in Prime Minister's Department told the media that executing FOI law in Malaysia requires additional resources, staffing and the installation of necessary infrastructure; hence it is not feasible in Malaysia ( $\mathrm{Ng}, 2015)$. On this issue, the Office of the Information Commissioner, Ireland (2001) acknowledges that the processing of FOI requests can impose a formidable administrative burden on public bodies. Submissions must be acknowledged within a statutory deadline, third parties notified in some instances where release is proposed, detailed reasons for any refusal must be given, and a right of appeal offered. However, the report also suggests several measures that can be used to reduce such a burden, such as:

- Developing a policy on releasing Information outside FOI; 
- Providing administrative access to information even when no request is made. In Ireland, The Department of Finance publishes the papers of the Tax Strategy Group on its website as soon as possible after the Minister's budget day speech;

- The procedures should not be too rigid and formal. Files not containing exempt records would sometimes be met simply by inviting the requester to inspect the relevant file and offering copies of any of the records which the requester wanted;

- Each public body should identify classes of documents that are likely to be of general interest and adopt procedures to ensure a proactive approach to releasing them.

In Malaysia, the Minister's claim of possible skyrocketing cost and the administrative burden was refuted by the Speaker of the Selangor's State Legislative Assembly. She stated that until August 2015, Selangor had appointed 41 information officers, and training did not cost the state government much, only RM4,362. Allowances for the Information Officers amounted to RM246,000 (Malaysian Insider, 2015). It is further submitted that government departments deal with information as part of their daily routine. Creating, receiving, classifying, organising, categorising and publishing information form part and parcel of the public officials' duties. Allowing public access to the information does not require significant alteration to their current scope of work, except for the fact that information requests will be formalised by way of statutory arrangement.

Reduction of public trust and confidence: The Independent Commission of FOI, UK (2015) notes the response from the Royal Marsden NHS Foundation Trust, which stated that there is a question as to whether the FOI Act is serving its original purpose or gives rise to the contrary. A key concern concerning the FOIA is that the legislation limits the agency's ability to build trust with general public members. The release of information misled by the requestor will also cause reputational damage that the trust has to use resources and time to dispel. Besides, data can be politically sensitive and embarrassing for the government. In such a situation, the objective assessment of whether the information should be withheld or published is challenging (Ross \& Whittaker, 2009). Quite to the contrary, it is submitted that FOI will further enhance the public trust in the government. When exposé on abuses or corruption is unearthed through FOI, and legal action is taken to punish the offenders, it will increase public confidence in the government. Further, one cannot treat cancer by hiding it from others.

Similarly, although abuses could potentially bring the government into disrepute, concealing the matter will not make the evil disappear. According to Dasan (2014), with active demand for information from the public, it builds a direct gateway between the government and the people. He further stated that this direct link of accountability and increased investigations and convictions against corrupt public officials will purportedly augment public faith in the government.

\section{Conclusion}

This article highlights both the justification for enacting FOI in Malaysia and the hurdles that it will encounter. This article proposes that prismatic construction to the Constitution should give life to FOI in Malaysia. Besides, this article also demonstrates the possible advantages of FOI and the arguments in opposition to the law. Enacting FOI 
law is a precondition towards engineering a system of openness and transparency. The tightly regulated framework of access under the Official Secrets Act 1972 requires a significant overhaul to facilitate the implementation of the right to know. As highlighted in this article, the great potentials of FOI outscore the concern regarding cost, administrative burden and negative effect of FOI on the government's reputation and image.

\section{Acknowledgement}

This study would not have been possible without the guidance and help of several individuals who in one way or another contributed and extended their valuable assistance in the preparation and completion of this study.

\section{Funding}

This study received no funding.

\section{Conflict of Interests}

The authors declare no conflict of interest in this study.

\section{References}

Corcoran, S. (2005). The architecture of interpretation: Dynamic practice and constitutional principles. In Corcoran, S. \& Bottomley, S. (Eds.), Interpreting statutes. New South Wales: Federation Press, pp. 31-51.

Cotterrell, R. (1995). Law's community: legal theory in sociological perspective. Oxford: Oxford University Press.

Dasan, K.S. (2014). Is Freedom of Information an Effective Strategy for Combating Corruption in Government Contracting? Canberra: Australia National University.

Flyn, C. \& Harper, C.Q. (22 March 2012) What price freedom (of information)? The Telegraph,http://www.telegraph.co.uk/news/politics/9149322/What-pricefreedom-of-information.html

Gill, S.S. (1998). Credibility and honesty. The Hindustan Times.

Lim, I. (21 September 2015) Court reverses three-month ban on The Edge. Malay Mail. http://www.themalaymailonline.com/malaysia/article/court-reverses-three-monthban-on-the-edge

M. Daud \& S. Zulhuda. (2018). Open Data and Right to Information in Malaysia: A Comparative Analysis. 6th International Conference on Cyber and IT Service Management (CITSM), 2018, pp. 1-5, doi: 10.1109/CITSM.2018.8674259.

Malaysian Insider (19 August 2015) Paul Low giving excuses on freedom of information law, says Selangor speaker. The Malaysian Insider at: http://www.themalaysianinsider.com/malaysia/article/paul-low-giving-excuses-onfreedom-of-information-law-says-selangor-speaker\#sthash.PBgbGVDO.dpuf

Mitee, L. (2017). The Right of Public Access to Legal Information: A Proposal for its Universal Recognition as a Human Right. German Law Journal, 18(6), 1429-1496. doi:10.1017/S2071832200022392

Ng, E. (18 August 2015) Not feasible to have freedom of information law for now, says Paul Low. 
http://www.themalaysianinsider.com/malaysia/article/not-feasible-to-havefreedom-of-information-law-for-now-says-paul-low\#sthash.pt1sUV5l.dpuf

Office of the Information Commissioner (2001) The Freedom of Information Act Compliance by Public Bodies. Dublin: Office of the Information Commissioner.

Paterson, M. (2004). Transparency in the modern state: Happy birthday FoI! Or commiserations?. Alternative Law Journal, 29(1), 10-14.

Ross, J., \& Whittaker, P. (2009). Freedom of Information: Is Openness Too Expensive, Too Difficult or Too Dangerous?. Journal of Finance and Management in Public Services, 7(1), 53-70.

Stearman, K. (2012). Freedom of information. New York: The Rosen Publishing Group.

The Independent Commission of FOI. (2015). Responses from organisations to call for evidence: $\mathrm{R}$ https://www.gov.uk/government/uploads/system/uploads/attachment_data/file /487269/Responses_R_-_Z.pdf 